\title{
Effects of Different Weather Conditions and Addition of Mangosteen Peel Powder on Chemical Properties and Antioxidant Activity of Coconut Sap
}

\author{
Pepita Haryanti ${ }^{1,2 *}$, Supriyadi ${ }^{3}$ Djagal Wiseso Marseno ${ }^{3}$, Umar Santoso $^{3}$ \\ ${ }^{1}$ Jenderal Soedirman University, Faculty of Agriculture, Department of Agricultural Technology, \\ Jl. Dr. Soeparno, Grendeng, Purwokerto, Central Java 53122, Indonesia \\ ${ }^{2}$ Doctoral program of Food Science, Gadjah Mada University, Faculty of Agricultural Technology, Department of Food \\ Technology and Agricultural Product Technology, Jl. Flora No. 1, Bulaksumur, Yogyakarta 55281, Indonesia \\ ${ }^{3}$ Gadjah Mada University, Faculty of Agricultural Technology, Department of Food and Agricultural Product \\ Technology, Jl. Flora No. 1, Bulaksumur, Yogyakarta 55281, Indonesia \\ *Email: pepita.haryanti@unsoed.ac.id
}

Submission: November $2^{\text {nd }}, 2017$; Acceptance: August $6^{\text {th }}, 2018$

\begin{abstract}
Coconut sap is sweet, oyster-white and translucent liquid which can be obtained by tapping coconut flowers for $8-12$ hours. Since it contains sugar with nearly neutral $\mathrm{pH}$, coconut sap is highly susceptible to spontaneous fermentation. In order to maintain the quality of the sap during the tapping process, coconut farmers usually add preservative substances. The preservatives can be produced either naturally, such as mixtures of lime, mangosteen peel and sliced jackfruit wood, or synthetic one, such as sodium metabisulphite. The chemical properties of coconut sap might be affected by weather conditions during the tapping process. This research aimed to determine the effect of weather conditions during tapping process and variations of mangosteen peel powder concentration on the chemical properties and antioxidant activity of the coconut sap. The results showed that the optimum preservative concentration of mangosteen peel powder was $0.84 \mathrm{~g} / \mathrm{L}$ of coconut sap which was tapped in sunny weather condition. This treatment yielded sap with chemical properties i.e. $\mathrm{pH}$ value of 6.7; total soluble solids of 16.2 brix; water content of $85.62 \%$; reducing sugar of $0.04 \mathrm{~g} / 100 \mathrm{~g}$; sucrose content of $13.64 \mathrm{~g} / 100 \mathrm{~g}$; total free amino acids of $0.1738 \mathrm{~g} / 100 \mathrm{~g}$; total phenolic of $323.23 \mathrm{mgGAE} / 100 \mathrm{~g}$; and vitamin C of $26.06 \mathrm{mg} / 100 \mathrm{~g}$. The antioxidant activity of this treatment was $34.39 \%$ RSA evaluated by DPPH method, this value, was relatively similar to that of the addition of 0.28 and $0.56 \mathrm{~g} / \mathrm{L}$ mangosteen peel powder. The coconut sugar produced had reducing sugar of $5.01 \mathrm{~g} / 100 \mathrm{~g}$; total sugar of $86.50 \mathrm{~g} / 100 \mathrm{~g}$; total phenolic content of 470 mgGAE/100 g; browning index of 16254 IU (ICUMSA); and antioxidant activity of $61.05 \%$ RSA.
\end{abstract}

Keywords: Antioxidant activity; coconut sap; mangosteen peel powder

\section{INTRODUCTION}

Coconut sap is sugary exudates, sweet, oysterwhite color and translucent, with nearly neutral $\mathrm{pH}$ that is obtained from young inflorescence of a coconut tree (Cocos nucifera L.) (Borse, Jagan, Rao, Ramalakshmi, \& Raghavan, 2007). This substance is rich in nutricious components such as sugar, proteins, vitamins, minerals, etc. Coconut sap can be processed into beverage or as a raw material of coconut sugar. Coconut sap is usually collected in a bamboo tube, which is placed at the tip of the cut inflorescence for tapping process at least for 8-12 hours (Hebbar et al., 2015). In general, coconut sap will suffer spontaneous fermentation and become alcoholic and acidic due to microbial activity (Hariharan, Singaravadivel, \& Alagusundaram, 2014).

Chemical properties of coconut sap usually change during the tapping period i.e. decreasing $\mathrm{pH}$ value and 
sucrose content. In order to maintain the quality of the sap during the tapping process, coconut farmers usually add a preservative substance such as lime, which is commonly used in order to inhibit fermentation. In spite of the fact that lime addition will increase the $\mathrm{pH}$ value of coconut sap, it is not effective to be utilized as a single preservative. A combination of several preservatives, thus, is needed to produce more effective inhibitory action. There are some natural preservatives, such as mangosteen peel and jackfruit wood, which are usually combined with lime as an anti-fermentation agent. Mangosteen peel contains a class of naturallyoccurring polyphenol compounds known as xanthonoids like a-mangostin and $\mathrm{y}$-mangostin. According to Nivetha \& Roy, (2015), ethanolic extract of mangosteen peel contains high amount of polyphenols $(3.717 \mu \mathrm{g} / \mathrm{ml})$ and flavonoids $(2.98 \mu \mathrm{g} / \mathrm{ml})$ which have capabilities as antioxidant and antimicrobial agents. It has been proved that xanthones and their derivatives have several benefits as an antioxidant and antibacterial. Hence, this research was carried out in order to inhibit the spontaneous fermentation in freshly-collected coconut sap using a combination of lime and mangosteen peel powder during the tapping process. The whole form of mangosteen peel which was usually used by coconut farmer may cause the liberation of the antibacterial compounds from mangosteen peel into lime milk not optimum. The use of powder form of mangosteen peel, however might liberate the antibacterial compounds more easily than the whole form.

Furthermore, as a tropical country, there are two weather in Indonesia, i.e. wet and dry season. The chemical properties of coconut sap were also influenced by the weather condition. Naknean, Meenune, \& Roudaut (2010) reported that the composition and quality of sap vary depending on place, time, season and duration of tapping. During dry season, sap will be favor for the rapid growth of microorganism. In this research, the chemical properties of coconut sap, i.e. $\mathrm{pH}$ value, water content, total soluble solids, reducing sugar, sucrose content, amino acid content, total polyphenol, vitamin $\mathrm{C}$ and antioxidant activity, were evaluated at three different weather conditions, i.e. sunny day, drizzling rain, and heavy rain. The chemical properties of coconut sap will, indeed, affect the properties of sugar produced. The sugar produced, therefore, was also analyzed its chemical properties, i.e. reducing sugar, total sugar, browning index, total phenolic and antioxidant activity.

The objectives of this research was to determine the effect of weather conditions and addition of mangosteen peel powder as a preservative on chemical properties of coconut sap.

\section{MATERIALS AND METHODS}

\section{Materials}

The coconut sap was tapped from spathes of tall variety of coconut (Cocos nucifera, L) trees (Dalam) cultivated in Sikapat Village, Sumbang District, Banyumas Regency, Central Java, Indonesia with altitude of 5001000 meters above sea level. Coconut sap was collected at three different weather conditions, namely sunny day, drizzling rain and heavy rain with average relative humidity of $91.5,92.5$ and $93.5 \%$, respectively. Coconut sap used in this research was obtained from April to May 2016.

\section{Chemicals}

The chemicals used, i.e. Rochelle salts, phenol, sodium sulphite, sodium hydroxide, hydrochloric acid, glucose anhydrous, Folin-Ciocalteu reagent, ethanol, gallic acid, natrium carbonate, dipotassium phosphate, potassium dihydrogen phosphate, phosphoric acid, 2,2`-dipyridyl, trichloroacetic acid, ferric trichloride, ninhydrin, stannous chloride, L-glutamic acid, ethanol and methanol,were purchased from Merck (Darmstadt, Germany). While 3,5-Dinitrosalicylic acid, and 2,2-diphenyl-1-picrylhydrazyl were obtained from Sigma-Aldrich (St. Louis, USA).

\section{Collection of coconut sap}

The coconut sap was obtained from tapped inflorescence of 15 coconut trees during night for 15 hours $(03.00 \mathrm{pm}-06.00 \mathrm{am})$. The sap was then collected into plastic containers which have been washed using hot water to minimize microbial contamination. The preservatives added to the sap were $1.7 \mathrm{~g} / \mathrm{L}$ lime with addition of $0,0.28,0.56$, and $0.84 \mathrm{~g} / \mathrm{L}$ of mangosteen peel powder. The control treatment was the preservative that is commonly used by local farmers, i.e. mixture of $1.7 \mathrm{~g} / \mathrm{L}$ of lime, $0.28 \mathrm{~g} / \mathrm{L}$ of jackfruit wood cuts and 0.28 $\mathrm{g} / \mathrm{L}$ of sliced mangosteen peel. The phenolic content of the preservatives are $2.1 ; 5.9 ; 7.0 ; 9.2$ and 3.7 mgGAE/100 g respectively.

The procedure of the tapping process was as follows. The tip of the coconut inflorescence was cut by a sterilized stainless steel knife. A plastic container with the preservatives substance inside was placed covered up the cut inflorescence to collect the coconut sap. The temperature of the collected coconut sap was maintained at $4^{\circ} \mathrm{C}$ in a cool box.

\section{Preparation of granulated coconut sugar}

A 2.0 L of coconut sap was filtered with a filter cloth, then poured into an aluminium pan, and subsequently 
heated using a gas stove for 2 hours. The sap was then continuously agitated during the heating process until the temperature of the sap reached $118^{\circ} \mathrm{C}$. After that, the viscous sap was still agitated at room temperature until the sap crystallized and granulated sugar was formed. The granulated sugar was then dried under sunlight to reduce its water content. The sugar product was observed visually afterward for the formation of sugar granule.

\section{Chemical analysis}

The coconut sap collected from the previous step was then analyzed its chemical and antioxidant properties, i.e. pH value, water content, total soluble solids, reducing sugar, sucrose content, total free amino acid, total phenolic, vitamin $C$ and antioxidant activity. Moreover, some of these properties, i.e. reducing sugar, total sugar, total phenolic, browning index and antioxidant activity, were also measured for the coconut sugar produced.

\section{pH value}

The $\mathrm{pH}$ value of the sap was measured using a digital pH meter (Ohaus-ST10-USA), which has been calibrated by using buffer solution with a $\mathrm{pH}$ of 6.86 at a temperature of $25 \mathrm{oC}$.

\section{Water content}

The water content of coconut sap was measured using thermogravimetric procedure according to AOAC (2005).

\section{Total soluble solids}

The total soluble solids was measured by a portable refractometer (Atago, Japan).

\section{Reducing sugar and sucrose content}

Reducing sugar and sucrose content were determined as described by modified method of Miller (1959). A volume of $3 \mathrm{~mL}$ of coconut sap sample was mixed with $3 \mathrm{~mL}$ of $1 \%$ 3,5-Dinitrosalicylic acid (DNS). The mixture was then heated at $90^{\circ} \mathrm{C}$ in water for 10 minutes and subsequently cooled at room temperature. To stabilize the color of the mixture, an amount of $1 \mathrm{~mL}$ of potassium tartrate $40 \%$ was added. The mixture was cooled afterward at room temperature and measured its absorbance at a wavelength of $575 \mathrm{~nm}$. A standard glucose solution was used to obtain standard curve and get the straight line equation to quantify samples. The total sugar of the coconut sap was determined by hydrolyzing the sample by incubating with $3 \mathrm{~mL}$ of
$25 \% \mathrm{HCl}$ at a temperature of 70 oC for 10 minutes. The mixture was then cooled at room temperature and neutralized with $\mathrm{NaOH} 45 \%$. Sucrose content was calculated by subtracting reducing sugar from total sugar.

\section{Total free amino acid content}

The amino acid was measured by applying the method of Yao et al. (2006). A weight of $1.0 \mathrm{~g}$ of coconut sap, $0.5 \mathrm{~mL}$ of buffer solution and $0.5 \mathrm{~mL}$ of ninhydrin solution were placed in a $25-\mathrm{mL}$ volumetric flask and the flask was subsequently heated in a boiling water bath for 15 minutes. The flask was then cooled at room temperature for 5 minutes and the solution in the flask was diluted by $25 \mathrm{~mL}$ of distilled water. The absorbance of the diluted solution was measured using Spectronic 200 (Thermoscientific) at $570 \mathrm{~nm}$. Glutamic acid was used to prepare the standard curve to quantify the samples.

\section{Total phenolic}

The estimation of the total phenolics content of the coconut sap was performed according to the FolinCiocalteu method with slight modifications (Payet, Sing, \& Smadja, 2005). Thirty microliters of sample was added with $150 \mu \mathrm{L}$ of $10 \%$ Folin-Ciocalteu reagent in a test tube. After incubated for 8 minutes, an amount of $120 \mu \mathrm{L}$ of $7.5 \% \mathrm{Na} 2 \mathrm{CO} 3$ disolved in distilled water must be added. The sample was then incubated for 1 hour at $30{ }^{\circ} \mathrm{C}$, and the absorbance at $765 \mathrm{~nm}$ was measured. For the blank measurement, the sample was replaced by an appropriate solvent which was subtracted from the absorbance at $765 \mathrm{~nm}$. The measurement result was then obtained by reporting the absorbance in the standard curve of gallic acid used as the standard phenolic compound. The results were expressed in milligrams of gallic acid equivalent per 100 gram of sample (mgGAE/100 $\mathrm{g}$ of sample).

\section{Vitamin C}

One milliliter of coconut sap was put in the Eppendorf tubes, then centrifuged at $5{ }^{\circ} \mathrm{C}$ for 20 minutes. Vitamin $C$ content of coconut sap was determined by means of a spectrophotometer according to the procedure conducted by Xia et al. (2011). A volume of $0.2 \mathrm{~mL}$ of sample was mixed with $0.8 \mathrm{~mL}$ of $0.2 \mathrm{~mol} / \mathrm{L}$ phosphate buffer, $\mathrm{pH} 8,0.8 \mathrm{ml}$ of $43 \%$ phosphoric acid, $0.8 \mathrm{ml}$ of $4 \% 2,2{ }^{\prime}$-dipyridyl, $1.0 \mathrm{ml}$ of $10 \%$ trichloroacetic acid, and $0.4 \mathrm{ml}$ of $3 \%$ ferric trichloride. The mixture was then incubated at $42^{\circ} \mathrm{C}$ in a water bath for 40 minutes and the absorbance was read at $525 \mathrm{~nm}$ using spectrophotometer UV 200. 


\section{Browning index}

The colour of granulated coconut sugar was determined in terms of the international unit of colour for sugary products according to International Commission for Uniform Methods of Sugar Analysis (ICUMSA) GS1/37 protocol (Asikin et al., 2014). Browning index was measured by preparing $25 \%$ coconut sugar solution and $\mathrm{pH}$ value was adjusted by $0.1 \% \mathrm{NaOH}$ solution until $\mathrm{pH} 7$ was reached. The coconut sugar solution was then filtered and measured by spectrophotometer at wavelength of $420 \mathrm{~nm}$. The brown color was calculated by the equation according to ICUMSA (International Commission for Uniform Methods of Sugar Analysis) as follows:

$$
\text { Color unit }(I U)=\frac{\text { Absorbance } \times 100}{b \times c}
$$

where:

$\mathrm{b}=$ cell path length $(\mathrm{cm})$

$\mathrm{C}=$ sample solution concentration $(\mathrm{g} / \mathrm{mL})$

\section{Antioxidant activity}

Antioxidant activity of coconut sap was measured using the radical DPPH scavenging activity method (Payet et al., 2005). A volume of $280 \mu \mathrm{L}$ of $0.1 \mathrm{mM}$ $\mathrm{DPPH} \bullet$ methanolic solution was pipetted into each tube test followed by $20 \mu \mathrm{L}$ of sample, or solvent for the blank. The mixture was subsequently incubated at room temperature for 30 minutes, and the absorbance at 515 $\mathrm{nm}$ was then measured with a spectrophotometer. The antioxidant activity can be evaluated as a percentage of the radical scavenging activity (RSA) using the following equation:

$$
R S A(\%)=\frac{A o-A s}{A o} \times 100
$$

where Ao is absorbance of the blank and As is absorbance of the sample at $515 \mathrm{~nm}$ after 30 minutes.

\section{Statistical Analysis}

The data of chemical properties and antioxidant activity were statistically analyzed using IBM SPSS Statistic 20 and reported as mean \pm standard deviation (SD). The differences among the experimental groups were identified by one-way analysis of variance (ANOVA) using Duncan's multiple range test. The statistical significance was considered at $\mathrm{P}<0.05$.

\section{RESULT AND DISCUSSION}

\section{pH value, water content and total soluble solids}

The variety of $\mathrm{pH}$, total soluble solids and water content of coconut sap tapped at different weather conditions and mangosteen peel powder concentrations are shown in Table 1.

According to Table 1, $\mathrm{pH}$ of the coconut sap ranged from 5.8 to 8.8. The addition of mangosteen peel powder as a preservative with concentration of 0.84 $\mathrm{g} / \mathrm{L}$ exhibited a better performance comparing to the other treatments. This treatment can improve the $\mathrm{pH}$ value of the coconut sap so that its acidity was nearly neutral with $\mathrm{pH}$ ranged from 6.7 to 7.1. The addition of $0.84 \mathrm{~g} / \mathrm{L}$ of mangosteen peel powder, contributed to the total phenolic content up to $9.2 \mathrm{mg} \mathrm{GAE} / 100 \mathrm{~g}$ of coconut sap. Palakawong, Sophanodora, Pisuchpen, \& Phongpaichit (2010) reported that xanthones, which

Table1. The pH value, water content and total soluble solids of coconut sap tapped at different weather conditions and variation of mangosteen peel powder concentrations.

\begin{tabular}{llccc}
\hline $\begin{array}{c}\text { Mangosteen peel } \\
\text { powder }(\mathrm{g} / \mathrm{L})\end{array}$ & Weather conditions & & Chemical properties & ; \\
\cline { 3 - 5 } & & $\mathrm{pH}$ & Water content (\%) & $\begin{array}{c}\text { Total soluble solids } \\
\text { ( } \mathrm{b} \text { brix })\end{array}$ \\
\hline 0 & Heavy rain & $5.9 \pm 0.1^{\mathrm{a}}$ & $90.31 \pm 0.16^{\mathrm{d}}$ & $12.0 \pm 0.2^{\mathrm{d}}$ \\
& Drizzle & $6.1 \pm 0.1^{\mathrm{a}}$ & $88.60 \pm 0.84^{\mathrm{c}}$ & $16.0 \pm 0.5^{\mathrm{e}}$ \\
& Sunny & $5.8 \pm 0.1^{\mathrm{a}}$ & $85.41 \pm 0.21^{\mathrm{ab}}$ & $16.0 \pm 0.5^{\mathrm{e}}$ \\
\hline 0.28 & Heavy rain & $6.6 \pm 0.1^{\mathrm{b}}$ & $91.96 \pm 0.37^{\mathrm{e}}$ & $11.2 \pm 0.1^{\mathrm{c}}$ \\
& Drizzle & $6.8 \pm 0.1^{\mathrm{bc}}$ & $86.42 \pm 1.19^{\mathrm{b}}$ & $16.8 \pm 0.1^{\mathrm{f}}$ \\
& Sunny & $7.0 \pm 0.3^{\mathrm{bc}}$ & $85.65 \pm 1.08^{\mathrm{ab}}$ & $16.8 \pm 0.2^{\mathrm{f}}$ \\
\hline 0.56 & Heavy rain & $6.7 \pm 0.1^{\mathrm{bc}}$ & $90.91 \pm 0.84^{\mathrm{de}}$ & $9.6 \pm 0.1^{\mathrm{b}}$ \\
& Drizzle & $6.8 \pm 0.1^{\mathrm{bc}}$ & $84.46 \pm 0.58^{\mathrm{a}}$ & $16.5 \pm 0.1^{\mathrm{ef}}$ \\
& Sunny & $6.7 \pm 0.1^{\mathrm{bc}}$ & $86.41 \pm 0.65^{\mathrm{b}}$ & $16.2 \pm 0.5^{\mathrm{ef}}$ \\
\hline 0.84 & Heavy rain & $7.1 \pm 0.1^{\mathrm{cd}}$ & $91.64 \pm 0.63^{\mathrm{de}}$ & $8.4 \pm 0.2^{\mathrm{a}}$ \\
& Drizzle & $6.9 \pm 0.1^{\mathrm{bc}}$ & $95.69 \pm 0.30^{\mathrm{f}}$ & $16.3 \pm 0.2^{\mathrm{ef}}$ \\
& Sunny & $6.7 \pm 0.4^{\mathrm{bc}}$ & $85.62 \pm 0.32^{\mathrm{ab}}$ & $16.2 \pm 0.3^{\mathrm{ef}}$ \\
\hline
\end{tabular}

Note: the data shown are obtained from three replication and are expressed in mean \pm standard deviation. Numbers in the same column with the same letter indicates no significant difference $(p>0.05)$. 
has efficacy as antioxidant and antibacterial agent, can be achieved from mangosteen pericarp. Despite the effectiveness of preservatives addition, the $\mathrm{pH}$ values of coconut sap collected at varied weather conditions were not significantly different.

As seen in Table 1., the water content of the coconut sap obtained in rainy conditions was 90.31 $91.96 \%$, which was higher than that obtained in sunny day $(85.41-86.56 \%)$. The variations of mangosteen peel powder concentration, however, did not significantly affect the water content of the coconut sap. The difference of water content of the coconut sap is caused by the variation of coconut cultivar as well as weather conditions and soils. The variation of coconut cultivars will lead to the difference of groundwater absorption ability. The higher ability to absorb water, the higher coconut sap will be produced. Furthermore, soil which has higher groundwater amount will make coconut trees can absorb more water. Heavy rain, therefore, will increase groundwater availability. According to Lantemona, Abadi, Rachmansyah, \& Pontoh (2013), the volume of coconut sap tapped in rainy season is higher than that in dry season.

Total soluble solids of the coconut sap tapped in heavy rain condition was $8.4-12.0^{\circ}$ brix, which was inferior to that in drizzle or in sunny day (Table 1 ). Furthermore, the coconut sap obtained in heavy rain contains more water so that it will reduce the total soluble solids of the sap. In addition, Lantemona, Abadi, Rachmansyah, \& Pontoh (2013) reported that in rainy season, the photosynthesis process cannot yield the maximum results due to less sunlight intensity. In relation to the metabolism aspect, this condition will become the limiting factor for photosynthesis to produce sugar. The results also indicate that the variations of mangosteen peel powder concentrations did not considerably affect the total soluble solids.

\section{Reducing sugar, sucrose and total free amino acid content}

The variety of reducing sugar, sucrose content and total free amino acids content of coconut sap tapped at different weather conditions and preservative concentrations is shown in Table 2.

According to Table 2, the reducing sugar decreased if the use of mangosteen peel powder increased. Using the more preservative will inhibit the invertase reaction that converts sucrose to reducing sugar. Naknean et al. (2010), reported that the inversion reaction was caused by invertase activity which either presented naturally or also synthesized by microorganisms. Moreover, the microorganisms can convert sucrose to glucose and fructose by invertase and finally to organic acids. The least amount of reducing sugar, i.e. $0.04 \mathrm{~g} / 100 \mathrm{~g}$, was produced from the combination treatment of coconut sap collected at sunny day and added with $0.84 \mathrm{~g} / \mathrm{L}$ mangosteen peel powder. Haryanti, Supriyadi, Marseno, \& Santoso (2017) reported that coconut sap which can be used as a raw material of coconut sugar should contain reducing sugar less than $0.48 \mathrm{~g} / 100 \mathrm{~g}$. Reducing sugar is the chemical property that substantially influence the forming of coconut sugar.

Table 2. The reducing sugar, sucrose content and total free amino acids of coconut sap tapped at different weather conditions and variation of mangosteen peel powder concentrations.

\begin{tabular}{lllll}
\hline $\begin{array}{c}\text { Mangosteen peel } \\
\text { powder }(\mathrm{g} / \mathrm{L})\end{array}$ & \multicolumn{1}{c}{$\begin{array}{c}\text { Weather } \\
\text { conditions }\end{array}$} & $\begin{array}{c}\text { Reducing sugar } \\
(\mathrm{g} / 100 \mathrm{~g})\end{array}$ & $\begin{array}{c}\text { Chemical properties } \\
(\mathrm{g} / 100 \mathrm{~g})\end{array}$ & $\begin{array}{c}\text { Total free amino acids } \\
(\mathrm{g} / 100 \mathrm{~g})\end{array}$ \\
\hline 0 & Heavy rain & $0.13 \pm 0.00^{\mathrm{cd}}$ & $6.14 \pm 0.41^{\mathrm{a}}$ & $0.0870 \pm 0.0086^{\mathrm{bc}}$ \\
& Drizzle & $0.35 \pm 0.03^{\mathrm{h}}$ & $9.04 \pm 0.11^{\mathrm{c}}$ & $0.1401 \pm 0.0155^{\mathrm{def}}$ \\
& Sunny & $0.15 \pm 0.01^{\mathrm{d}}$ & $10.50 \pm 0.55^{\mathrm{d}}$ & $0.2479 \pm 0.0176^{\mathrm{h}}$ \\
\hline 0.28 & Heavy rain & $0.11 \pm 0.00^{\mathrm{c}}$ & $6.00 \pm 0.78^{\mathrm{a}}$ & $0.0628 \pm 0.0038^{\mathrm{b}}$ \\
& Drizzle & $0.24 \pm 0.03^{\mathrm{f}}$ & $9.45 \pm 0.44^{\mathrm{c}}$ & $0.0981 \pm 0.0222^{\mathrm{c}}$ \\
& Sunny & $0.11 \pm 0.01^{\mathrm{c}}$ & $13.13 \pm 0.88^{\mathrm{e}}$ & $0.2818 \pm 0.0425^{\mathrm{i}}$ \\
\hline 0.56 & Heavy rain & $0.05 \pm 0.01^{\mathrm{b}}$ & $7.93 \pm 0.67^{\mathrm{b}}$ & $0.0210 \pm 0.0063^{\mathrm{a}}$ \\
& Drizzle & $0.13 \pm 0.01^{\mathrm{cd}}$ & $11.09 \pm 0.82^{\mathrm{d}}$ & $0.1446 \pm 0.0116^{\mathrm{def}}$ \\
& Sunny & $0.13 \pm 0.01^{\mathrm{cd}}$ & $13.34 \pm 0.31^{\mathrm{e}}$ & $0.2131 \pm 0.0103^{\mathrm{g}}$ \\
\hline 0.84 & Heavy rain & $0.02 \pm 0.00^{\mathrm{a}}$ & $6.60 \pm 0.40^{\mathrm{a}}$ & $0.0211 \pm 0.0025^{\mathrm{a}}$ \\
& Drizzle & $0.05 \pm 0.00^{\mathrm{b}}$ & $13.52 \pm 0.34^{\mathrm{e}}$ & $0.1131 \pm 0.0053^{\mathrm{cd}}$ \\
& Sunny & $0.04 \pm 0.01^{\mathrm{ab}}$ & $13.64 \pm 0.22^{\mathrm{e}}$ & $0.1738 \pm 0.0447^{\mathrm{f}}$ \\
\hline control & Heavy rain & $0.03 \pm 0.01^{\mathrm{ab}}$ & $7.78 \pm 0.49^{\mathrm{b}}$ & $0.0239 \pm 0.0001^{\mathrm{a}}$ \\
& Drizzle & $0.31 \pm 0.05^{\mathrm{g}}$ & $9.20 \pm 0.16^{\mathrm{c}}$ & $0.1529 \pm 0.0012^{\mathrm{ef}}$ \\
& Sunny & $0.20 \pm 0.02^{\mathrm{e}}$ & $12.81 \pm 0.69^{\mathrm{e}}$ & $0.1345 \pm 0.0104^{\mathrm{de}}$ \\
\hline
\end{tabular}

Note: the data shown are obtained from three replication and are expressed in mean \pm standard deviation. Numbers in the same column with the same letter indicates no significant difference $(p>0.05)$. 
The sucrose content of coconut sap varies from $6.00-13.64 \mathrm{~g} / 100 \mathrm{~g}$. The more preservative addition, the higher the sucrose content. The highest sucrose content, i.e. $13.64 \mathrm{~g} / 100 \mathrm{~g}$, was found in coconut sap which was collected at sunny day with addition of 0.84 $\mathrm{g} / \mathrm{L}$ of mangosteen peel powder (Table 2). The smallest sucrose content, on the other hand, was obtained from coconut sap tapped at heavy rain condition. During heavy rain condition, the less intensity of sunlight may cause the photosynthesis not optimum. According to El-Naggar \& Swedan (2009), the less intensity of sunlight reduced total non structural carbohydrate content, especially sucrose. Sucrose content has significant effects on coconut sugar production. Moreover, the minimum sucrose content of coconut sap to be used as the raw material of coconut sugar is $10.39 \mathrm{~g} / 100 \mathrm{~g}$, as reported by Haryanti, Supriyadi, Marseno, \& Santoso (2017).

The lowest free amino acids content was found in the coconut sap tapped at heavy rain conditions, comparing to that at drizzling rain and sunny day (Table 2). Higher use of preservatives produces a variety of free amino acids. The variation of mangosteen peel powder concentrations resulted in varied free amino acids content from 0.0210 to $0.2818 \mathrm{~g} / 100 \mathrm{~g}$. The variation of of protein content in coconut sap may also be due to the different sources of coconut sap. Microorganisms may use protein as a carbon source or as a nitrogen source for their metabolism and genetic material (Naknean et al., 2010). Moreover, free amino acids is the essential component of non-enzymatic browning, i.e. Maillard reaction. In addition, the products of Maillard reaction are, for instance, the substances responsible for the unique aroma of sugar, the reductone compound and melanoidin which can be employed as antioxidants.

\section{Correlation of the chemical properties of coconut sap}

The correlation analysis between the $\mathrm{pH}$ value, water content, total soluble solids, reducing sugar, sucrose content and total free amino acids of coconut sap is presented in Table 3. The result reveals that the positive Pearson coefficients, occur between reducing sugar and total soluble solids (0.527); sucrose content and total soluble solids (0.749); total free amino acid content and total soluble solids $(0.778)$; total free amino acids and reducing sugar (0.302); and total free amino acids and sucrose content (0.691). The positive correlation means if one property increases the other one also increases. The high amount of total soluble solids is caused by the high amount of total free amino acids, sucrose and reducing sugar. According to Choong, Anzian, Sapawi, \& Hussin (2016), the sugar compounds contributed to soluble solids components in coconut sap.

The result of the multiple linear regression test showed that the reducing sugar (X1) had a significant effect on the total soluble solid of coconut sap (Sig. $t=$ $0.000)$. The concentration of sucrose $(X 2)$ and the free amino acid (X3) also had a significant influence linearly to total soluble solid of coconut sap with significance value $t=0.000$ and 0.010 , respectively. The three parameters have significant effect (Sig. $F=0.000)$ to the total soluble solid of coconut sap $(Y)$ according to the multiple regression equation: $Y=4.376+14.404$ $\mathrm{X} 1+0.661 \mathrm{X} 2+9.487 \mathrm{X} 3$ with $\mathrm{R}=0.927$. Thus the total soluble solid change is proportional to the change of reducing sugar, sucrose and total free amino acids in the coconut sap.

\section{Total phenolic, vitamin C and antioxidant activity}

The variety of total phenolic, vitamin $C$ and antioxidant activity of coconut sap tapped at different weather conditions and preservative concentrations is given in Table 4. The result reveals that tapping at sunny day showed that the addition of mangosteen peel powder was significantly different on phenolic total of coconut sap. The total phenolic content of the sap added with $0.84 \mathrm{~g} / \mathrm{L}$ of mangosteen peel powder was not significantly different with the total phenolic content of sap added with $0.28 \mathrm{~g} / \mathrm{L}$ of mangosteen peel powder i.e. $323.23 \mathrm{mg} / 100 \mathrm{~g}$ dan $313.75 \mathrm{mg} / 100$ $\mathrm{g}$, respectively. A research conducted by Hebbar et al. (2015) reported that total polyphenol in coconut sap varies between 4.80 to $5.40 \mathrm{mg} / 100 \mathrm{ml} \mathrm{GAE}$. Xia et al.

Table 3. Pearson correlation matrix of chemical properties of coconut sap

\begin{tabular}{llccc}
\hline \multicolumn{1}{c}{ Chemical properties } & $\begin{array}{c}\text { Total soluble } \\
\text { solids }\end{array}$ & Reducing sugar & Sucrose content & $\begin{array}{c}\text { Total free amino } \\
\text { acids }\end{array}$ \\
\hline Total soluble solids & 1 & & & \\
Reducing sugar & $0.527^{* *}$ & 1 & 1 & 1 \\
Sucrose content & $0.749^{* *}$ & 0.004 & $0.691^{* *}$ & 1 \\
Total free amino acids & $0.778^{* *}$ & $0.302^{*}$ & & \\
\hline
\end{tabular}

Note: $*$ Correlation is significant at the 0.05 level (2-tailed)

$* *$ Correlation is significant at the 0.01 level (2-tailed) 
Table 4. Total phenolic, vitamin C and antioxidant activity of coconut sap tapped at different weather conditions and variation of mangosteen peel powder concentrations.

\begin{tabular}{|c|c|c|c|c|}
\hline \multirow{2}{*}{$\begin{array}{c}\text { Mangosteen peel } \\
\text { powder }(\mathrm{g} / \mathrm{L})\end{array}$} & \multirow{2}{*}{$\begin{array}{l}\text { Weather } \\
\text { conditions }\end{array}$} & \multicolumn{3}{|c|}{ Antioxidant properties } \\
\hline & & $\begin{array}{c}\text { Total phenolic } \\
(\mathrm{mg} / 100 \mathrm{~g})\end{array}$ & $\begin{array}{l}\text { vitamin C (mg/100 } \\
\mathrm{g})\end{array}$ & $\begin{array}{c}\text { Antioxidant activity } \\
\text { (\% RSA) }\end{array}$ \\
\hline \multirow[t]{3}{*}{0} & Heavy rain & $125.51 \pm 2.37^{\text {cde }}$ & $17.25 \pm 6.59 \mathrm{bc}$ & $25.35 \pm 0.60^{c}$ \\
\hline & Drizzle & $148.21 \pm 3.18^{\mathrm{e}}$ & $47.20 \pm 6.32^{\mathrm{e}}$ & $19.00 \pm 0.62^{b}$ \\
\hline & Sunny & $189.27 \pm 41.15^{f}$ & $24.74 \pm 1.65^{c}$ & $9.12 \pm 3.99^{a}$ \\
\hline \multirow[t]{3}{*}{0.28} & Heavy rain & $140.56 \pm 14.56^{\text {de }}$ & $9.76 \pm 1.08^{\mathrm{ab}}$ & $49.31 \pm 3.18^{\mathrm{e}}$ \\
\hline & Drizzle & $131.60 \pm 4.16^{\text {cde }}$ & $66.14 \pm 4.36^{f}$ & $59.14 \pm 1.08^{f}$ \\
\hline & Sunny & $313.75 \pm 5.85^{\mathrm{h}}$ & $66.14 \pm 10.25^{f}$ & $36.14 \pm 7.97^{d}$ \\
\hline \multirow[t]{3}{*}{0.56} & Heavy rain & $101.70 \pm 4.18^{\mathrm{ab}}$ & $11.53 \pm 2.71^{\mathrm{ab}}$ & $44.79 \pm 4.77^{e}$ \\
\hline & Drizzle & $132.87 \pm 9.03^{\text {cde }}$ & $66.58 \pm 1.08^{f}$ & $48.39 \pm 0.00^{e}$ \\
\hline & Sunny & $289.15 \pm 3.72^{\mathrm{g}}$ & $36.19 \pm 5.71^{d}$ & $34.39 \pm 5.40^{d}$ \\
\hline \multirow[t]{3}{*}{0.84} & Heavy rain & $118.06 \pm 5.99^{\mathrm{bcd}}$ & $25.62 \pm 1.08^{c}$ & $37.15 \pm 5.74^{d}$ \\
\hline & Drizzle & $127.28 \pm 3.56^{\text {cde }}$ & $41.03 \pm 2.71^{\mathrm{de}}$ & $66.67 \pm 2.84^{\mathrm{g}}$ \\
\hline & Sunny & $323.23 \pm 3.93^{h}$ & $26.06 \pm 1.65^{c}$ & $34.39 \pm 1.61^{d}$ \\
\hline \multirow[t]{3}{*}{ control } & Heavy rain & $92.79 \pm 2.40^{a}$ & $6.68 \pm 1.65^{a}$ & $25.00 \pm 1.04^{c}$ \\
\hline & Drizzle & $116.23 \pm 1.23^{b c}$ & $40.59 \pm 3.79^{\text {de }}$ & $49.46 \pm 1.08^{e}$ \\
\hline & Sunny & $133.99 \pm 5.83^{\text {cde }}$ & $8.44 \pm 1.08^{\mathrm{ab}}$ & $30.53 \pm 2.11^{\mathrm{cd}}$ \\
\hline
\end{tabular}

Note: the data shown are obtained from three replication and are expressed in mean \pm standard deviation. Numbers in the same column with the same letter indicates no significant difference $(p>0.05)$.

(2011) showed that the fresh coconut sap contains total polyphenol of $0.33 \mathrm{~g} / \mathrm{L}$. In addition, phenolic compound in coconut sap consists of gallic acid, protocatechuic acid, caffeic acid, p-coumaric acid, and galangin. The increase of total polyphenol can be caused by the using of mangosteen peel powder. The using of 0.28 until 0.84 $\mathrm{g} / \mathrm{L}$ mangosteen peel powder contributes total phenolic of $2.1-9.2 \mathrm{mg} \mathrm{GAE} / 100 \mathrm{~g}$.

Table 4. shows that the sap tapped at drizzle with addition of $0.56 \mathrm{~g} / \mathrm{L}$ mangosteen peel powder contains the highest of vitamin C content $(66.58 \mathrm{mg} / 100 \mathrm{~g})$. Hebbar et al. (2015), reported that vitamin C content in coconut sap is about $17.5 \mathrm{mg} / 100 \mathrm{~mL}$. Xia et al. (2011) reported that fresh sap contains vitamin C of $20.4 \mathrm{mg} / \mathrm{L}$. The difference of vitamin $\mathrm{C}$ content might be due to the activity of microorganism especially yeast which synthesized vitamin C in fermentation.

Chemical compounds which play as antioxidant in coconut sap are polyphenol and vitamin C (Xia et al., 2011). According to Table 4., the addition of mangosteen peel powder could increase the radical scavenging activity. The sap tapped at drizzle with addition of 0.84 $\mathrm{g} / \mathrm{L}$ of mangosteen peel powder showed the highest antioxidant activity evaluated with DPPH methods, i.e. $66.67 \%$ RSA. Mangosteen peel powder contains a class of naturally-occurring polyphenol compounds known as xanthonoids like a-mangostin and $y$-mangostin. Xanthones and their derivatives have been shown to have several benefits, including antibacterial and antioxidant activity (Nivetha \& Roy, 2015).

\section{Correlation of the antioxidant properties of coconut sap}

The correlation analysis between the Vitamin C, total phenolic and antioxidant activity of coconut sap is shown in Table 5. The results show there is a positive correlation between antioxidant activity and vitamin C content of coconut sap. The higher the vitamin $\mathrm{C}$ content, the higher the antioxidant activity of the coconut sap will be. According to Xia et al. (2011) vitamin $\mathrm{C}$ and phenolic compounds are the important antioxidant agents that protect biomacromolecule from the damage induced by free radical.

The result of non linear regression test showed that vitamin $C(X 1)$ had significant effect on antioxidant activity $(Y)$ of coconut sap according to cubic equation $Y=9.030+78.287 X 1-279.777 X 12+323.688 X 13$ with $\mathrm{R}=0.640$. In addition, the total phenolic content (X2) had significant effect on the antioxidant activity $(Y)$ of coconut sap according to the quadratic equation $Y=-6.000+3.368 \times 2-0.126 \times 22$ with $R=0.788$.

Table 5. Pearson correlation matrix of antioxidant properties of coconut sap

\begin{tabular}{llll}
\hline $\begin{array}{l}\text { Antioxidant } \\
\text { properties }\end{array}$ & Vitamin C & $\begin{array}{l}\text { Total } \\
\text { phenolic }\end{array}$ & $\begin{array}{l}\text { Antioxidant } \\
\text { activity }\end{array}$ \\
\hline Vitamin C & 1 & & \\
Total phenolic & 0.284 & 1 & \\
Antioxidant activity & $0.298^{*}$ & -0.202 & 1 \\
\hline
\end{tabular}

Note: $*$ Correlation is significant at the 0.05 level (2-tailed) 
Table 6. The chemical and antioxidant properties of coconut sugar produced

\begin{tabular}{lllcccc}
\hline $\begin{array}{c}\text { Mangosteen } \\
\text { peel powder } \\
(\mathrm{g} / \mathrm{L})\end{array}$ & $\begin{array}{l}\text { Weather } \\
\text { conditions }\end{array}$ & $\begin{array}{c}\text { Reducing } \\
\text { sugar } \\
(\mathrm{g} / 100 \mathrm{~g})\end{array}$ & $\begin{array}{c}\text { Total sugars } \\
(\mathrm{g} / 100 \mathrm{~g})\end{array}$ & $\begin{array}{c}\text { Total phenolics } \\
(\mathrm{mg} / 100 \mathrm{~g})\end{array}$ & $\begin{array}{c}\text { Browning } \\
\text { index (IU) }\end{array}$ & $\begin{array}{c}\text { Antioxidant } \\
\text { activity } \\
(\% \mathrm{RSA})\end{array}$ \\
\hline 0 & Heavy rain & 10.33 & 82.23 & 1020 & 57447 & 68.55 \\
& Drizzle & 14.33 & 82.23 & 490 & 71612 & 68.55 \\
& Sunny & 11.20 & 89.23 & 470 & 32246 & 62.71 \\
\hline 0.28 & Heavy rain & 6.78 & 81.38 & 1140 & 54989 & 62.57 \\
& Drizzle & 8.18 & 91.07 & 400 & 36250 & 62.57 \\
& Sunny & $4.80^{*}$ & 84.80 & 360 & 18009 & 67.79 \\
\hline 0.56 & Heavy rain & 7.77 & 85.94 & 650 & 41858 & 60.18 \\
& Drizzle & $3.27 *$ & 92.94 & 460 & 36871 & 60.18 \\
& Sunny & $3.60 *$ & 85.40 & 450 & 19290 & 62.39 \\
\hline 0.84 & Heavy rain & 6.02 & 86.45 & 1320 & 36979 & 63.30 \\
& Drizzle & $3.02 *$ & 96.45 & 470 & 74594 & 63.30 \\
& Sunny & $5.01^{*}$ & 86.50 & 470 & 16254 & 61.05 \\
\hline \multirow{2}{*}{ control } & Heavy rain & 11.50 & 92.53 & 1610 & 56147 & 68.22 \\
& Drizzle & 10.50 & 97.53 & 510 & 73675 & 68.22 \\
& Sunny & 12.50 & 86.30 & 500 & 14458 & 67.79 \\
\hline
\end{tabular}

Note: Numbers with starred symbol indicate that those values meet to BSN standard

The results of t-test showed that vitamin $\mathrm{C}$ and total phenolic content independently affected antioxidant activity of coconut sap (Sig. 2-tailed $=0.000$ ).

\section{The chemical and antioxidant properties of coconut sugar produced}

The sugar produced of coconut sap have chemical and antioxidant properties, as shown in Table 6. The result indicates that coconut sugar made from the coconut sap which were tapped at sunny day and with the addition of mixture of lime and all of mangosteen peel powder concentration have the reducing sugar accordance with (BSN, 1995) i.e. maximum 6.0\%. Same result for coconut sugar made from the coconut sap which was tapped at drizzling rain and with the addition of mixture of lime and 0.56 and $0.84 \mathrm{~g} / \mathrm{L}$ mangosteen peel powder. According to Haryanti, Supriyadi, Marseno, \& Santoso (2017), the coconut sap appropriate as raw material of coconut sugar that was tapped in fine weather.

\section{CONCLUSION}

The addition of mangosteen peel powder as preservatives can maintain the $\mathrm{pH}$ value, however, it has no significant effect on total soluble solids. The variation of weather conditions during tapping process does not affect $\mathrm{pH}$ value of the coconut sap. The tapping process at sunny day, yet, produces coconut sap with lower water content and higher total soluble solids. The addition of mangosteen peel powder of $0.84 \mathrm{~g} / \mathrm{L}$ resulted in coconut sap with lower reducing sugar and higher sucrose content. Additionally, total free amino acids decreased along with the increase of mangosteen peel powder. As for the effect of weather conditions, coconut sap with low reducing sugar as well as high sucrose content and total free amino acids can be produced by tapping at sunny day. The increase of mangosteen peel powder yielded the rise of total phenolics of the coconut sap, however vitamin C content of the sap decreased. Moreover, the addition of $0.84 \mathrm{~g} / \mathrm{L}$ of mangosteen peel powder produced coconut sap with higher antioxidant activity. With regard to the effect of weather conditions, coconut sap collected during sunny day gave high total phenolic and low vitamin C content. However, coconut sap collected during drizzle rain, had higher vitamin $\mathrm{C}$ and antioxidant activity.

\section{ACKNOWLEDGMENT}

This project was financially supported by Ministry of Research, Technology and Higher Education through Flagship Research Universities, 2016.

\section{REFERENCES}

AOAC. (2005). Official Methods of Analysis of AOAC International. (W. Horwitz \& W. Latimer, George, Eds.) (18th ed.). Maryland: AOAC International.

Asikin, Y., Kamiya, A., Mizu, M., Takara, K., Tamaki, H., \& Wada, K. (2014). Changes in the physicochemical characteristics, including flavour components and Maillard reaction products, of non-centrifugal cane 
brown sugar during storage. Food Chemistry, 149, 170177. https://doi.org/10.1016/j.foodchem.2013.10.089.

Borse, B. B., Jagan, L., Rao, M., Ramalakshmi, K., \& Raghavan, B. (2007). Chemical composition of volatiles from coconut sap (neera) and effect of processing. Food Chemistry, 101, 877-880. https://doi.org/10.1016/j. foodchem.2006.02.026.

BSN. (1995). SNI 01-3743-1995 tentang Gula palma. Badan Standarisasi Nasional.

Choong, C., Anzian, A., Sapawi, C. W., \& Hussin, M. (2016). Characterization of Sugar from Arenga pinnata and Saccharum officinarum sugars. International Food Research Journal, 23(4), 1642-1652.

El-Naggar, A. H., \& Swedan, E. A. (2009). Effect of Light Intensity and Amino Acid Tryptophan on The Growth and Flowering of Amaryllis (Hippeastrum vittatum, Herb.) Plants. Journal of Agriculture and Environmental Sciences, 8(1), 22-42.

Hariharan, B., Singaravadivel, K., \& Alagusundaram, K. (2014). Effect of Food Grade Preservatives on the Physicochemical and Microbiological Properties of Coconut Toddy during Fermentation. Journal of Nutrition and Food Sciences, 4(5), 1-5. https://doi.org/10.4172/2155-9600.1000299.

Haryanti, P., Supriyadi, Marseno, D. W., \& Santoso, U. (2017). Chemical Properties of Coconut Sap Obtained at Different Tapping Time and Addition of Preservatives. The International Journal Of Science \& Technoledge, 5(3), 52-59. Retrieved from www.theijst.com.

Hebbar, K. B., Arivalagan, M., Manikantan, M. R., Mathew, A. C., Thamban, C., Thomas, G. V, \& Chowdappa, P. (2015). Coconut inflorescence sap and its value addition as sugar - collection techniques, yield, properties and market perspective. Current Science, 109(8), 1411-1417.

Lantemona, H., Abadi, A. L., Rachmansyah, A., \& Pontoh, J. (2013). Impact of Altitude and Seasons to Volume ,
Brix Content , and Chemical Composition of Aren Sap in North Sulawesi. IOSR Journal of Environmental Science, Toxicology and Food Technology, 4(2), 42-48.

Miller, G. L. (1959). Use of DinitrosaIicyIic acid reagent for determination of reducing sugar. Analitical Chemistry, 31(3), 426-428.

Naknean, P., Meenune, M., \& Roudaut, G. (2010). Characterization of palm sap harvested in Songkhla province, Southern Thailand. International Food Research Journal, 17, 977-986.

Nivetha, S., \& Roy, D. V. (2015). Antioxidant activity and antimicrobial studies on Garcinia Mangostana. American Journal of Biological and Pharmaceutical Research, 2(3), 129-134.

Palakawong, C., Sophanodora, P., Pisuchpen, S., \& Phongpaichit, S. (2010). Antioxidant and antimicrobial activities of crude extracts from mangosteen (Garcinia mangostana L.) parts and some essential oils. International Food Research Journal, 17, 583-589.

Payet, B., Sing, A. S. C., \& Smadja, J. (2005). Assessment of Antioxidant Activity of Cane Brown Sugars by ABTS and DPPH Radical Scavenging Assays : Determination of Their Polyphenolic and Volatile Constituents. Journal of Agricultural and Food Chemistry, 53, 10074-10079.

Xia, Q., Li, R., Zhao, S., Chen, W., Chen, H., Xin, B., ... Tang, M. (2011). Chemical composition changes of post-harvest coconut inflorescence sap during natural fermentation. African Journal of Biotechnology, 10(66), 14999-15005. https://doi.org/10.5897/AJB10.2602.

Yao, L., Xu, L., Jiang, Y., Caffin, N., D'Arcy, B., Singanusong, R., ... Xu, Y. (2006). Compositional analysis of teas from Australian supermarkets. Food Chemistry, 94, 115-122. https://doi.org/10.1016/j.foodchem.2004.11.009. 